\title{
SPESIASI DAN BIOGEOGRAFI IKAN DI KAWASAN SEGITIGA
}

\section{TERUMBU KARANG}

\author{
Fione Yukita Yalindua ${ }^{1 *}$ \\ ${ }^{1}$ Pusat Penelitian Oseanografi, Lembaga Ilmu Pengetahuan Indonesia \\ Jl. Pasir Putih I, Ancol Timur, Jakarta Utara, 14430 \\ *Alamat email: yukitayalindua@gmail.com
}

\begin{abstract}
The coral triangle is a region with the highest hotspot of fish biodiversity in the world. Factors to explain biodiversity in the coral triangle are varied widely. Factors as well as biogeography and speciation in evolutionary processes would explain the richness of fish species. The species formation theory in fish (speciation) is divided into allopatric, sympatric, and parapatric speciations. Biogeographically, the reason of what causes high biodiversity in the coral triangle area is divided into several models, namely: the center of origin, the center of overlap, the center of accumulation, the center of survival/refugia, and the mid domain effect/null model. This article will discuss the role and contribution of each mode/hypothesis in explaining coral triangle areas' biodiversity hotspots to provide information for biodiversity conservation of reef fishes in the future.
\end{abstract}

Keywords: reeffish, coral reef triangle, speciation, biogeography.

\section{PENDAHULUAN}

Ikan karang merupakan ikan yang hidup pada wilayah pesisir sampai dengan kedalaman $200 \mathrm{~m}$ di sekitar terumbu karang dan hidup dari masa juvenile sampai dewasa di wilayah ini (Nybakken, 1992; Allen, 1998). Sampai sekarang jenis ikan karang yang tercatat di dunia adalah lebih dari 5.000 spesies dan tersebar di wilayah tropis dan sub-tropis yang terbentang dari wilayah Indo-Pasifik memanjang ke laut merah, bagian timur Afrika sampai ke Pulau Hawaii dan Easter Island (Randall, 1998; Bellwood et al., 2010). Kawasan segitiga terumbu karang (Coral Triangle) yang adalah bagian dari kawasan IndoPasifik merupakan salah satu lokasi dengan tingkat biodiversitas/ kenakeragaman ikan karang tertinggi di dunia.Saat ini tercatat ada sekitar 2.600 spesies ikan karang diwilayah segitiga terumbu karang dan diperkirakan masih lebih banyak lagi (Tornabene et al., 2015).

Tingginya tingkat keanekaragaman spesies ikan di habitat segitiga terumbu dipengaruhi oleh berbagai faktor, salah satunya adalah faktor biogeografi yang menurut Cowman (2014) memiliki peran penting pada pembentukan diversitas ikan karang, melalui studi terbaru di bidang filogeni molekular pada beberapa dekade terakhir. Keanekaragaman spesies dapat dijelaskan melalui konsep biogeografi yaitu gabungan faktor biologi evolusi seperti spesiasi, kekerabatan, endemisasi, kepunahan, serta faktor geologi dan iklim di masa lalu (Abrar, 2011; Bellwood et al., 2012; Cowman, 2014). Biogeografi dan hipotesis terbentuknya spesies (spesiasi) merupakan kajian yang saling berkaitan dan tidak bisa dipisahkan dalam menjelaskan keanekaragaman spesies sebab studi tentang proses evolusioner yang 
dikaitkan dengan distribusi geografis terbukti berperan penting dalam pembentukan pola sejarah biogeografis sehingga dapat menjelaskan proses evolusi dan perannya dalam membentuk diversitas pada area geografis tertentu (Hodge \& Bellwood, 2016). Area geografis dengan tingkat diversitas yang tinggi dengan istilah pusat biodiversitas (biodiversity hotspot) seperti kawasan segitiga terumbu karang dapat menyediakan informasi dan kesempatan untuk mempelajari sejarah evolusi dan peran wilayah geografis dalam spesiasi karena memiliki data keanekaragaman yang besar, khususnya untuk keanekaragaman ikan karang (Hodge \& Jcu, 2014). Spesiasi yang termasuk dalam ranah biogeografi adalah salah satu hal penting dalam menjelaskan berbagai proses evolusi yang dengannya menjelaskan pembentukan spesies dalam situasi geografis yang berbeda (Hewitt, 2001; Hollocher, 2013).

Informasi terkait biogeografi dan spesiasi bermanfaat dalam memberikan informasi mengenai preservasi biodiversitas ikan di kawasan segitiga terumbu karang, karena dalam tujuan utama konservasi adalah tidak hanya untuk melindungi spesies yang ada sekarang, tetapi juga untuk melindungi proses alamiah yang berperan dalam pembentukan spesies baru (Hollocher, 2013).

\section{SPESIASI}

Proses terbentuknya spesies disebut dengan spesiasi yang merupakan suatu proses evolusioner pembentukan suatu spesies baru dari populasi yang sebelumnya telah ada dan dalam prosesnya membentuk kladogramnya sendiri (Cook, 1906). Menurut Wu dan Ting (2004) secara genetis spesiasi merupakan proses dimana dua populasi yang identik menyimpang secara genetik, sehingga menyebabkan kedua populasi tidak dapat digabungkan kembali dan menjadi dua spesies yang berbeda secara morfologi dan independen (isolasi reproduksi). Pada dasarnya proses spesiasi pada ikan karang terdiri dari tiga model yaitu secara alopatrik (isolasi menyeluruh), parapatrik (isolasi sebagian) dan simpatrik (tumpang tindih) dan ketiga model tersebut melibatkan gene flow dan isolasi geografis (Roche, 2007). Berbagai teori dan penelitian telah banyak dilakukan untuk menemukan jawaban mengenai awal mula spesiasi dan penyebab begitu tingginya biodiversitas ikan yang ada di wilayah Indo-Pasifik (termasuk pusat biodiversitas wilayah segitiga terumbu karang) diantaranya adalah:

\section{Spesiasi alopatrik}

Spesiasi alopatrik secara umum dikenal dengan spesiasi geografis. Spesiasi alopatrik terbentuk ketika populasi biologi dari spesies yang sama menjadi terisolasi karena perubahan geografis contohnya seperti pembentukan gunung, pergeseran lempeng, pembentukan pulau baru atau perubahan sosial seperti emigrasi (Rocha \& Bowen, 2008). Jika dibandingkan dengan Biological Species Concept (BSC) yang merupakan individual yang secara alami dapat kawin dan memproduksi keturunan yang fertil, maka spesies yang terbentuk secara alopatrik mengalami isolasi secara post-zygotic pada sistem reproduksinya, hal ini mengakibatkan spesies yang terisolasi secara alopatrik tidak mampu untuk bereproduksi secara seksual dengan spesies yang terpisah darinya saat proses alopatrik terjadi. Walaupun pada kenyataannya ada beberapa bukti ditemukannya vertebrata dan invertebrata yang tidak mengalami isolasi reproduksi walaupun telah 
mengalami spesiasi secara alopatrik (Cabej, 2012; Levin, 1999). Penggunaan model ini dalam mempelajari mengenai spesiasi ikan masih dipertanyakan karena kondisi laut yang besar dan mempunyai sedikit barrier atau batasan ditambah dengan kemampuan ikan yang awal reproduksinya berupa larva yang bisa terdispersi/tersebar di seluruh bagian laut (Mora \& Sale, 2002). Salah satu bukti yang mendukung spesiasi ikan karang dengan teori ini adalah spesiasi allopatrik karena terpisahnya populasi spesies akibat batasan geografis karena peristiwa alam (vicariance). Peristiwa karena batasan geografis ini diakibatkan oleh naiknya pulau Isthmus Panama sehingga memisahan ikan-karang dari Laut Karibia dan Kawasan Pasifik Timur sekitar 3 juta tahun yang lalu (Bermingham et al., 1997; Knowlton \& Weigt, 1998). Selain peristiwa isolasi geografis karena alam (vicariance) di beberapa kasus, peristiwa penyebaran/dispersal larva yang langka dapat mengarah pada kolonisasi pada area yang jauh dari asalnya yang mengarah pada aliran gen yang terisolasi dengan populasi awal. Beberapa contoh kasus yang terjadi akibat dispersal contohnya antara ikan karang di pulau-pulau kawasan Pasifik Tengah dibandingkan dengan ikan yang memiliki tingat endemisitas yang tinggi seperti Pulau Hawai dan Marquesas (Allen, 2008; Randall, 2007). Pada wilayah perairan Hindia Timur, selama kurun waktu 700.000 tahun telah terjadi tiga kali period glasial yang telah menurunkan permukaan laut yang mengisolasi Selat Torres, Selat Maluku dan Selat Sunda yang dapat berkontribusi terhadap spesiasi alopatrik karena faktor dispersal dan kolonisasi (Randall, 1998).

Contoh lain dari penelitian yang mendukung spesiasi alopatrik adalah ditemukannya spesies ikan karang yang memiliki kekerabatan yang dekat pada lokasi-lokasi yang kemungkinan menjadi wilayah terjadinya spesiasi alopatrik yang dinamakan dengan spesies geminate atau sering juga disebut dengan sister spesies (Gambar 1, 2). Sister spesies merupakan istilah yang digunakan untuk dua spesies yang sebelumnya merupakan spesies yang sama namun mengalami pemisahan dalam proses evolusi, sehingga secara genetis memiliki kekerabatan paling dekat (Dawson et al., 2002). Sister spesies (berkerabat paling dekat) yang ditemukan pada habitat geografis yang berbeda dapat membuktikan fenomena spesiasi alopatrik dan dapat menjelaskan kemungkinan spesies tersebut berevolusi menjadi spesies yang berbeda ketika dua lautan terpisah, contohnya seperti yang terjadi pada beberapa spesies dalam genus Amphiprion dan Siganus (Randall, 1998). Teori ini juga didukung oleh Leray et al., (2010) yang mendukung spesiasi alopatrik setelah melakukan evaluasi terhadap Dascyllus trimaculatus di kawasan Indo-Pasifik menggunakan kombinasi DNA mitokondria dan DNA nukleus, hasil analisis menunjukkan pengelompokan spesies ini berdasarkan wilayah geografis yang berbeda.

Beberapa penelitian telah dilakukan untuk membuktikan terjadinya spesiasi alopatrik dengan berdasarkan adanya sister spesies yang terpisah secara geografis, dan tidak tumpang tindih pada wilayah geografis yang sama contohnya dari famili Chaetodontidae seperti Chaetodon trifasciatus yang hanya tersebar di laut Hindia termasuk di dalamnya pulau NTT dan Sumatera dan Chaetodon lunulatus yang tersebar di lautan Pasifik termasuk Papua New Guinea, sampai Filipina dan Jepang (Waldrop et al., 2016). Chaetodon falcula di Lautan Hindia (Bagian Barat 
Indonesia) dan Chaetodon ulietensis di Lautan Pasifik (Indonesia, Filipina, Jepang). Chaetodon guttatissimus (Lautan Hindia) dan Chaetodon puctatofasciatus (Lautan Pasifik), Chaetodon madagascariensis (Lautan Hindia) dan Chaetodon xanthurus (Lautan Pasifik diantaranya Indonesia, Filipina sampai Jepang) (Blum, 1989). Terdapat banyak contoh lain sister spesies dari famili ikan karang lain yang menunjukkan batasan antara lautan Hindia dan Pasifik misalnya Naso literatus dan Naso elegans (Acanthuridae), Bodianus diana dan Bodianus dictynna (Labridae) dan masih banyak lagi (Gaither \& Rocha, 2013).

\section{Spesiasi simpatrik}

Spesiasi simpatrik adalah spesiasi tanpa isolasi geografis atau spesiasi antar populasi yang menunjukan migrasi bebas atau tidak adanya batasan wilayah (Coyne
\& Orr, 2004). Mekanisme ini cukup langka karena karena hanya dengan aliran gen yang sedikit akan menghilangkan perbedaan genetika antara satu bagian populasi dengan bagian populasi lainnya. Spesiasi simpatrik adalah unik karena terjadi hanya sementara antara dua subpopulasi dari spesies yang sama dan menempati wilayah yang sama atau berbagi wilayah sehingga tumpang tindih (overlapping). Meskipun area dimana organisme hidup adalah sama, mereka dapat dibagi menjadi dua kelompok berbeda secara genetis, sehingga tidak lagi dapat saling bereproduksi (Rocha, 2008). Walaupun spesiasi jenis ini masih diperdebatkan dalam menjelaskan biodiversitas pembentukan spesies ikan yang baru, beberapa penelitian mendukung adanya teori ini. Jones et al., (2003) meneliti mengenai seleksi reproduksi ber-

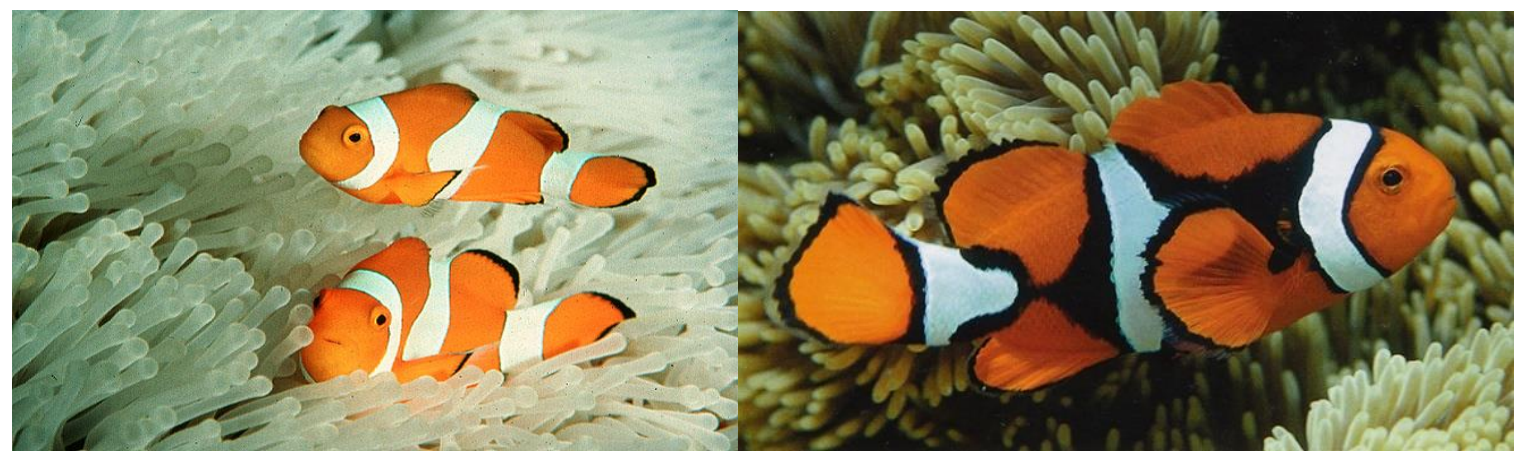

Gambar 1. Amphiprion ocellaris, Sulawesi, Indonesia (Randall, 1998) dan Amphiprion percula, Papua New Guinea (Allen \& Erdmann, 2012).

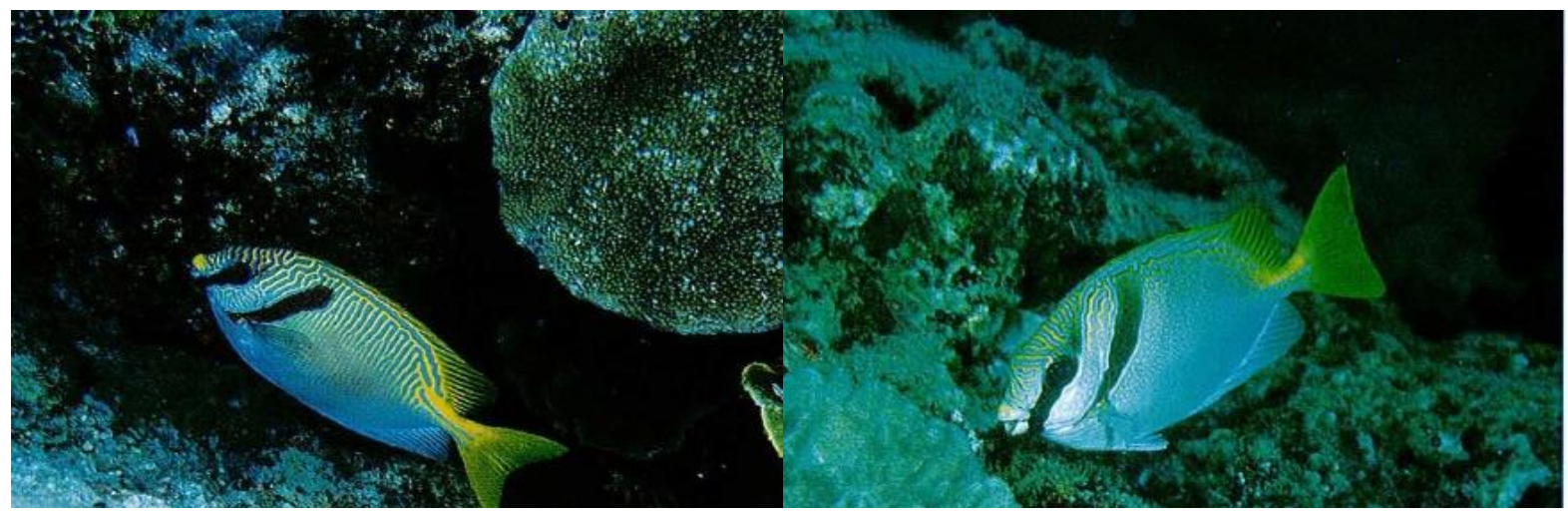

Gambar 2. Siganus doliatus, Heron Island dan Siganus virgatus, Sri Lanka (Randall, 1998). 
dasarkan ukuran tubuh yang menjelaskan spesiasi dari dua jenis sister spesies dari kuda laut (genus Hippocampus) yang berdistribusi tumpang tindih di wilayah Atlantis Barat dan Pasifik Barat. Penelitian menunjukan bahwa betina lebih memilih untuk kawin dengan jantan yang memiliki tubuh dengan ukuran yang sama sehingga menghasilan distribusi fenotip bimodal berdasarkan ukuran tubuh yang dapat mengarahkan terjadinya spesiasi simpatri pada populasi. Penelitian lain yang mendukung teori spesiasi simpatrik juga ditemukan pada triplefins (family Tripeterygiidae) di New Zealand. Wellenreuther et al., (2007) mempelajari mengenai distribusi ekologis dan geografis, penelitian ini menemukan bahwa banyak sister spesies yang hidup dalam wilayah geografis yang sama namun berbeda habitatnya, dimana sister spesies ditemukan di lokasi sama namun tidak pernah dalam kedalaman atau derajat paparan gelombang yang sama.

Selain faktor yang diakibatkan oleh seleksi reproduktif, terdapat beberapa contoh penemuan yang mendukung spesiasi simpatrik dengan faktor adaptasi yaitu pada genus Hypoplectrus. Terdapat sekitar 10 spesies dari genus Hypoplectrus yang tumpang tindih dalam distribusinya dan secara bentuk morfometrik dan meristik identik, namun satu-satunya karakter yang membedakan adalah warna (Graves \& Rosenblatt, 1980). Menurut Puebla et al., (2007), diversitas warna pada Hypoplectrus diakibatkan oleh tekanan seleksi di habitat yang menyebabkan terjadinya adaptasi untuk menyesuaikan warna tubuh menyerupai spesies yang tidak mengancam dalam menarik mangsa dan selanjutnya terjadinya juga seleksi kawin dimana Hypoplectrus lebih memilih kawin dengan yang memiliki warna yang sama. Hal yang mirip juga terjadi pada Parachirrhites arcatus di wilayah IndoPasifik yang yang memiliki warna yang berbeda karena jenis adaptasi pada mikrohabitat yang berbeda (kedalaman) pada habitat yang sama, apabila perbedaan pada warna mempengaruhi seleksi kawin, maka proses spesiasi simpatrik akan terjadi (Whitney et al., 2018). Kasus pada Hypoplectrus dan Parachirrhites arcatus menunjukkan bahwa terdapat peran adaptasi pada proses spesiasi simpatrik, hal ini didukung oleh Rolán-Alvarez (2007) yang mengemukakan bahwa spesiasi merupakan by-product dari adaptasi ekologi.

Contoh beberapa bukti genetik juga menunjukan terjadinya spesiasi simpatrik adalah pada genus Centropyge (DiBattista et al., 2012; Schultz et al., 2007). Spesiasi simpatrik yang terdapat pada genus Centropyge dibuktikan pada warna morfologi tubuh namun perbedaan tersebut tidak didukung oleh penanda genetik. Yang menjadi pembeda pada level genetiknya adalah berdasarkan wilayah geografis, dimana ikan yang warnanya berbeda memiliki kekerabatan yang lebih dekat jika dibandingkan dengan yang warnanya sama pada wilayah yang berbeda (DiBattista et al., 2012). Beberapa contoh spesies yang termasuk dalam sister spesies namun mempunyai warna morfologis yang berbeda dan tumpang tindih (overlapping) pada habitat yang sama dapat diamati pada Gambar 3.

Beberapa teori terbaru terkait dengan spesiasi simpatrik adalah kecenderungan terjadinya hibridisasi. Contoh spesiasi simpatrik pada Hypoplectrus menunjukkan adanya spesiasi yang sedang berlangsung 
(ongoing speciation) dan hibridisasi (kawin silang) (McCartney et al., 2003; Ramon et al., 2003; Rocha \& Bowen, 2008). Fenomena ongoing speciation dan hibridisasi pada jenis spesiasi simpatrik diperjelas oleh Abbott et al., (2013) dan Harrison et al., (2017) pada penelitiannya terhadap genus Plectopomodus di habitat terumbu karang. Peneliti tersebut mengemukakan bahwa hibridisasi lebih mungkin terjadi pada spesies dengan kekerabatan yang dekat dalam kondisi habitat yang tumpang tindih pada spesies simpatrik, tetapi teori tersebut sampai saat ini masih menjadi perdebatan para ahli, karena untuk dapat masuk dalam kategori ongoing speciation spesies hasil hibridisasi harus mampu menghasilkan individu baru yang reproduktif, sedangkan menurut Schumer et al., (2015) individu hasil hibridisasi tidak lagi bersifat reproduktif karena isolasi reproduksi yang diakibatkan inkompatibilitas/ketidakcocokan genetis.

\section{Spesiasi Parapatrik}

Spesiasi parapatrik adalah spesiasi yang terjadi karena adanya variasi frekuensi kawin dalam suatu populasi yang menempati wilayah terpisah namun tidak terisolasi secara penuh, sehingga masih terjadi aliran gen namun sangat terbatas (Hollocher, 2013). Dalam spesiasi parapatrik tidak ada pembatas (barrier) yang ekstrinsik untuk gene flow. Pada spesiasi seperti ini isolasi reproduksi berkembang dalam beberapa gene flow di antara populasi yang terbatas habitatnya dan tidak terjadi isolasi habitat sepenuhnya, seperti yang terjadi pada spesiasi alopatrik dan simpatrik, namun masih terdapat zona kontak yang menjadi tempat bertemunya

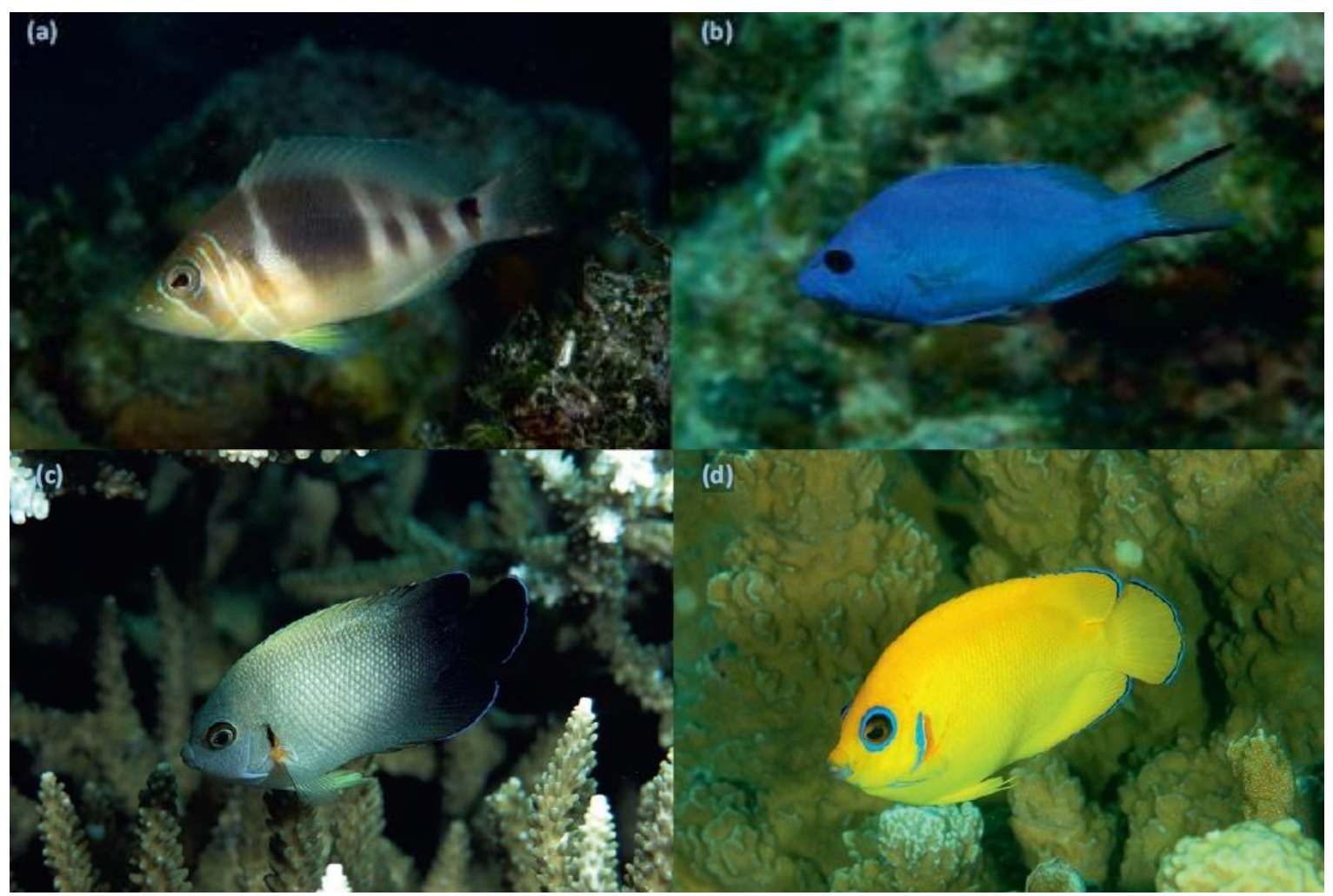

Gambar 3. Sister spesies dengan perbedaan warna yang mencolok dan tumpang tindih pada habitat yang sama, a) Gypoplectrus puella dan b) Gypoplectrus gemma dari Laut Karibia, c) Centropyge vrolikii dan d) Centropyge flavissima dari Pasifik Barat (Bowen et al., 2013). 
dua populasi divergen (telah mengalami spesiasi), dimana zona ini disebut dengan zona hybrid (Bayer, 1996; Hewitt, 2001). Pada populasi tersebut terdapat suatu perubahan alel yang berdampak pada terjadinya isolasi reproduktif, sehingga spesies-spesies dalam populasi tersebut tidak dapat melakukan perkawinan atau pertukaran gen (Widodo, 2003).

Pada spesiasi parapatrik dikenal dua model. Model clinal adalah perbedaan dalam distribusi spesies dan model stepping tone adalah spesies yang terpisah pada populasi yang berbeda. Menurut Rocha \& Bowen (2008) model stepping stone merupakan model yang dapat menjelaskan terjadinya spesiasi pada ikan karang, karena habitat terumbu karang sangat terfragmentasi, dimana di dalamnya kebanyakan spesies terdiri dari populasi yang terdistribusi secara terpisah-pisah namun dihubungkan dengan larva pelagis yang terdispersi.

Spesiasi dengan gene flow yang terbatas dapat menjelaskan kenekaragaman yang terjadi pada spesies laut. Menurut Coyne \& Orr (2004), dua faktor yang sangat berpengaruh pada spesiasi parapatrik antara lain adalah: (1) Spesies yang tersebar pada wilayah geografis yang luas dan terbagi-bagi pada populasi yang terpisah-pisah; dan (2) Variasi temporal dan spasial pada kondisi ekologis.
Menurut Rocha et al., (2005), terdapat empat faktor yang dapat mempengaruhi spesiasi parapatrik ikan dan organisme yang hidup pada habitat terumbu karang yaitu, (1) Spesies dengan jangkauan luas yang terbagi dalam beberapa populasi; (2) Kebanyakan larva tidak terdispersi terlalu jauh dari tempat asal induknya yang menetap; (3) wilayah biogeografi yang dipisahkan oleh barrier yang tidak sepenuhnya tertutup, dan (4) Habitat terumbu karang yang memiliki spasial, temporal dan lingkungan yang sangat beraneka ragam (contoh: tropis vs. subtropik, pulau dataran tinggi vs. pulau dataran rendah).

Salah satu contoh dari ikan karang yang terbentuk melalui spesiasi parapatrik adalah Chaetodontoplus poliourus dan Chaetodontoplus mesoleucus (Randall \& Rocha, 2009). Perbedaan dari kedua spesies tersebut terdapat pada warna ekor (Gambar 4). Spesies C. poliorus terdistribusi di wilayah Timur Samudera Hindia yang tersebar mulai dari Papua Nugini, Palau sampai ke Solomon Island, sedangkan C.mesoleucus terdistribusi pada habitat geografis di wilayah Pasifik (Jepang) dan Indo-Pasifik. Namun spesies C.poliorus dan C. mesoleucus bertemu dalam satu wilayah (hybrid zone) di sekitar Maluku, Halmahera dan Kepala Burung Papua (Gambar 5).

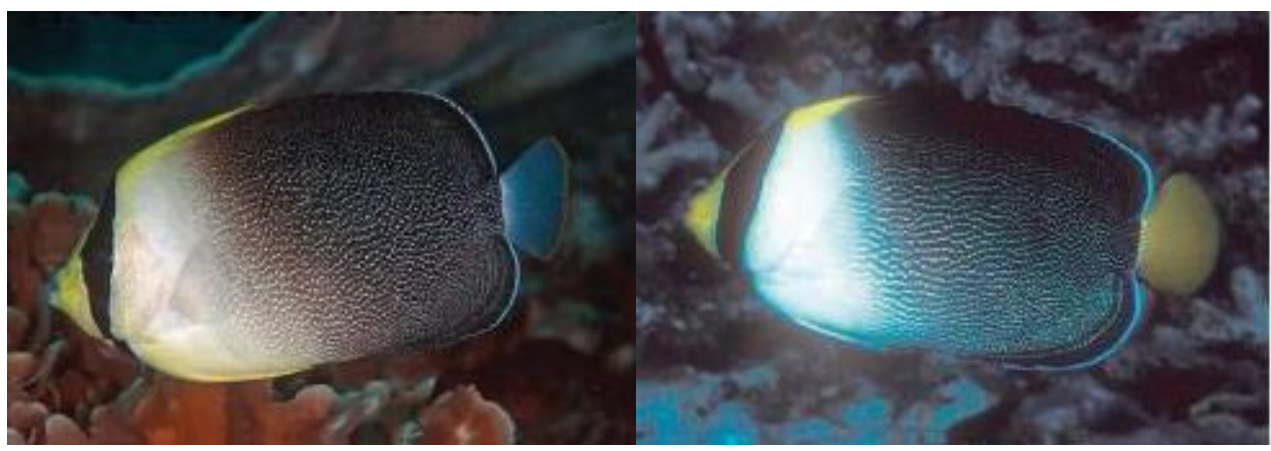

Gambar 4. Chaetodontoplus poliorus, Palau dan Chaedontoplus mesoleucus Kerama Islands, Okinawa (Randall \& Rocha, 2009). 


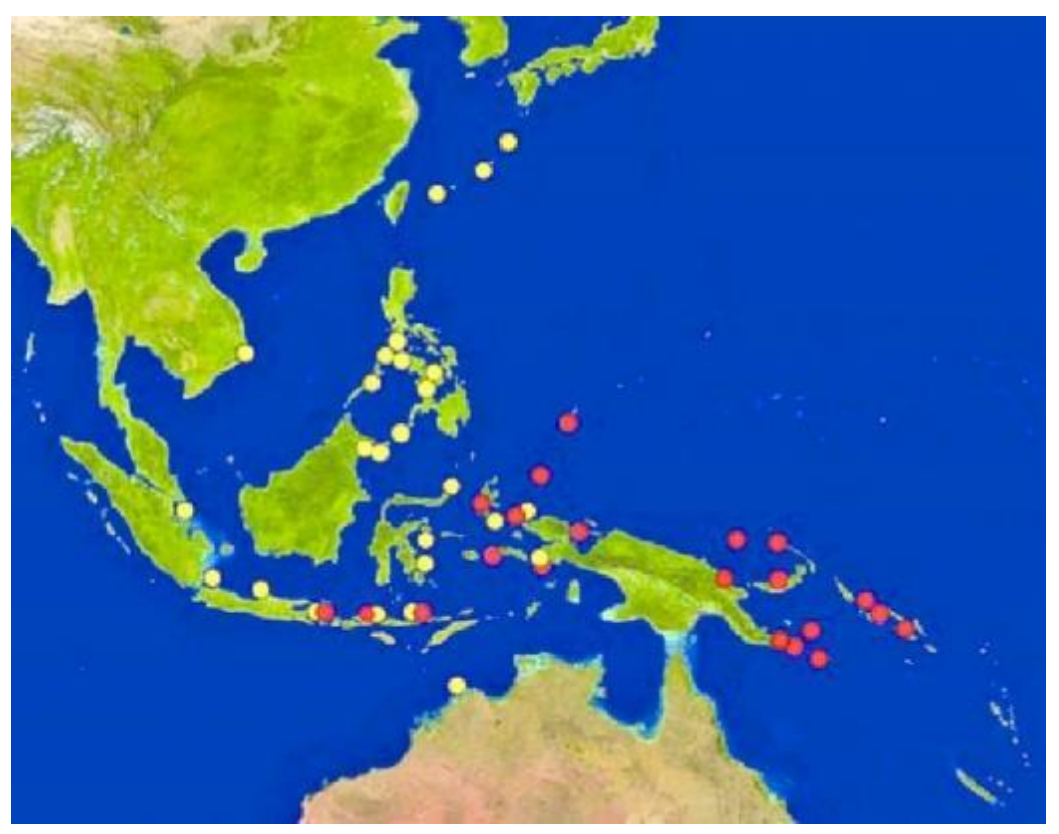

Gambar 5. Peta distribusi C. poliorus (titik merah) dan C. mesoleucus (titik kuning) (Randall \& Rocha, 2009).

\section{BIOGEOGRAFI IKAN DI KAWASAN SEGITIGA TERUMBU KARANG}

Biogeografi adalah ilmu tentang pola distribusi dan keanekaragaman spesies serta keterkaitannya antar proses biologi-ekologi, evolusi dan kejadiankejadian geologis yang saling mendukung dalam skala ruang dan waktu (Abrar, 2011). Menurut Posadas et al., (2006) biogeografi memberikan gambaran sebaran dan distribusi suatu spesies yang akan memberikan penguatan terhadap mekanisme spesiasi. Randall (1998) menyatakan bahwa biogeografi dapat menjelaskan kekayaan spesies ikan yang ada di wilayah Indo-Pasifik yang diantaranya termasuk Laut Cina Selatan dan Kawasan Segitiga Terumbu Karang yang terdiri atas 13.000 pulau di Indonesia, 7.000 pulau di Filipina dan terbentang sampai ke Solomon Island. Beberapa teori telah dikembangkan untuk menjelaskan alasan mengapa ikan di wilayah ini memiliki biodiversitas ikan yang tinggi dari sudut pandang biogeografis. Salah satu teori menurut (Randall, 1998), meliputi:

Stabilitas temperatur air laut selama periode glasial

Tingkat kepunahan pada biota lebih tinggi pada wilayah yang berada di lokasi lintang tinggi terutama pada perairan yang dipengaruhi oleh arus dengan suhu dingin, sedangkan bagian wilayah perairan yang berada dekat dengan ekuator memiliki temperatur yang stabil.

\section{Struktur geologis}

Luas wilayah Hindia Timur yang termasuk di dalamnya adalah wilayah segitiga terumbu karang, dengan luas antara $20^{\circ} \mathrm{LU}-10^{\circ} \mathrm{LS}$ dan $95^{\circ} \mathrm{BT}-160^{\circ}$ $\mathrm{BB}$ tergolong sangat besar, sehingga sejalan dengan teori bahwa semakin besar area, semakin kecil kemungkinan terjadi kepunahan. Ditambah dengan banyaknya pulau dengan bentuk insular shelf, contohnya paparan Sunda, sebagai tempat bertemunya dua benua dengan perbedaan sejarah geologi yang menciptakan habitat perairan laut yang beraneka ragam seperti: 
muara besar, pesisir, karang berbatu, tanjung berbatu, hutan mangrove, dasar berlumpur, padang lamun, perairan dengan kombinasi salinitas rendah dan kekeruhan tinggi dan lain-lain. Diversitas habitat ini yang menyebabkan banyak spesies yang hidup di wilayah segitiga terumbu karang.

\section{Perkembangan larva}

Tahap perkembangan larva ikan yang berada pada wilayah landas kontinen Asia, seperti paparan Sunda, berbeda dengan wilayah perairan lainnya, karena kebanyakan ikan pada tahap perkembangan larva telah beradaptasi dengan wilayah yang kaya akan plankton, sehingga akan kesulitan pada proses perkembangannya di wilayah dengan produktivitas plankton yang rendah.

Kapasitas untuk menjadi habitat bagi larva ikan yang telah mengalami evolusi secara signifikan

Menurut Randall, (1998) arus yang mengarah ke wilayah ekuatorial menjadi media pengantar spesies ikan karang dari berbagai wilayah yang telah mengalami evolusi sebelumnya. Teori ini memiliki kemiripan dengan model pusat akumulasi (Bowen et al., 2013).

Berbeda dengan Randall (1998), Bowen et al., (2013) menggolongkan penyebab tingginya diversitas ikan di wilayah segitiga terumbu karang ke dalam tiga model yaitu (1) model pusat akumulasi (center of accumulation); (2) model pusat tumpang tindih (center of overlap model); dan (3) model pusat spesiasi (center of speciation model), dimana pada dasarnya sama dengan model pusat asal-usul (center of origin) dan sampai sekarang dikenal dengan tiga model utama (Gambar 6, 7, 8). Selain itu mirip dengan tiga model tersebut, Bellwood et al., (2012) mengelompokkan model yang mendukung keanekaragaman ikan yang tinggi di wilayah terumbu karang khususnya kawasan Segitiga Terumbu Karang ke dalam lima model, dua di antaranya masuk dalam kategori tambahan/non-eksklusif, yaitu pusat pertahanan (center of survival/refugia) dan Mid Domain Effect (MDE)/null. Sampai saat ini, berbagai model yang masih banyak diuji oleh para peneliti di antaranya adalah:

\section{Model Pusat Asal-usul (Center of Origin)}

Model pusat asal-usul merupakan salah satu teori utama Darwin, dimana semua spesies berasal dari satu tempat yang sama dan mengalami persebaran ke berbagai wilayah (Gambar 6). Salah satu faktor yang mendukung teori ini adalah mayoritas ikan karang memiliki fase larva, sehingga dapat tersebar dengan bebas ke berbagai tempat (Bellwood et al., 2012). Menurut Briggs (1999), kawasan segitiga terumbu karang merupakan pusat asal-usul (center of origin) dengan tingkat spesiasi ikan karang yang tinggi. Spesies baru yang melimpah di wilayah segitiga terumbu karang kemudian mengalami dispersal sehingga tersebar di wilayah sekitarnya. Dalam model pusat asal-usul digambarkan bahwa spesies yang berada di kawasan segitiga terumbu karang umumnya memiliki umur spesiasi yang lebih muda dibandingkan dengan spesiesnya yang berkerabat dekat (sister spesies) di luar wilayah ini, karena spesies tetuanya telah mengalami proses dipersal pada masa lalu (Goldberg et al., 2005; Roy \& Goldberg, 2007). Penelitian yang mendukung model ini adalah Tornabene et al., (2015) yang meneliti tentang spesiasi famili Gobiidae dan 


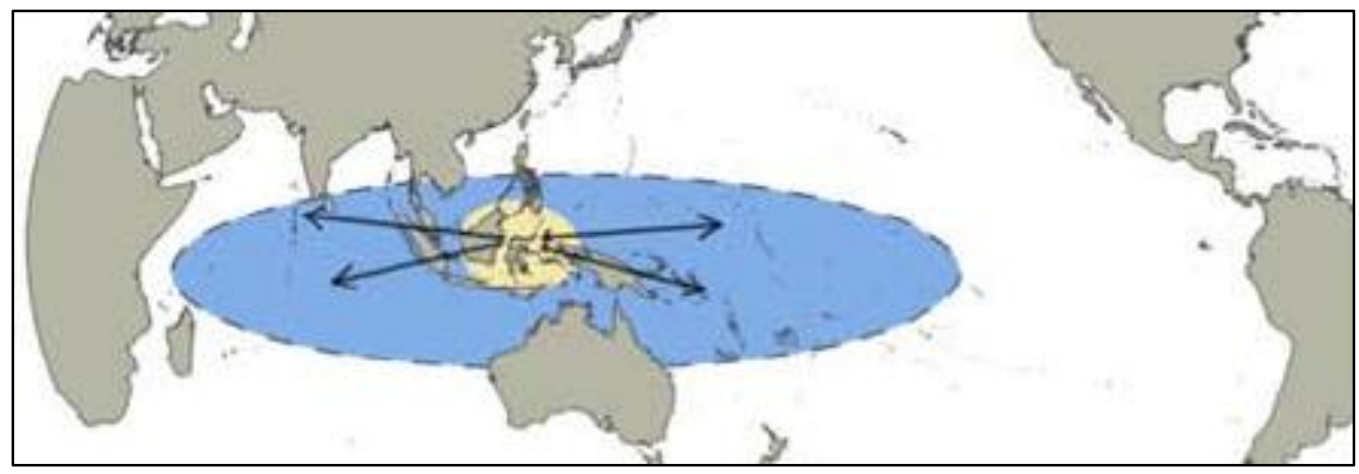

Gambar 6. Model pusat asal-usul (Gaboriau et al., 2018).

menyoroti pentingnya kawasan segitiga terumbu karang dalam membentuk biodiversitas baru melalui mekanisme spesiasi in-situ, dimana hal ini dibuktikan dengan melimpahnya spesies Gobiidae dan umur spesiasi spesies dalam famili Gobiidae yang masih tergolong baru/muda.

\section{Model Pusat Tumpang Tindih (Center of Overlap Hypothesis)}

Model pusat tumpang tindih menegaskan tingginya diversitas spesies di segitiga terumbu karang sebagai-hasil dari tumpang tindih, yaitu campuran fauna dari samudera Pasifik dan Hindia (Hodge \& Bellwood, 2016) (Gambar 7) sebagai akibat dari proses mekanisme isolasi yang terjadi pada batas lautan Indo-Pasifik yang memisahkan kedua samudera tersebut pada saat terjadi fenomena penurunan air laut di masa lalu. Menurut Gaither and Rocha (2013), mekanisme isolasi terjadi di wilayah paparan Sunda dan Sahul (Indonesia), Malaysia dan Australia Utara yang dikenal dengan wilayah batas IndoPasifik (Indo-Pasific Barrier). Dalam model ini spesies ikan karang dari Pasifik dan Hindia mengalami isolasi dan spesiasi ketika terjadi penurunan permukaan air di masa lalu yang memisahkan kedua wilayah tersebut. Ketika massa air laut kembali naik, sister spesies yang terbentuk dan semula terpisah mulai terdispersi kembali dan mengalami tumpang tindih (overlap) di wilayah segitiga terumbu karang (Bellwood \& Meyer, 2009).

Beberapa contoh penelitian yang mendukung model pusat tumpang tindih telah dilakukan oleh beberapa ahli dengan menggunakan studi dengan pendekatan genetika molekular/filogeografi,yaitu pada Linckia laevigata (Kochzius et al.,

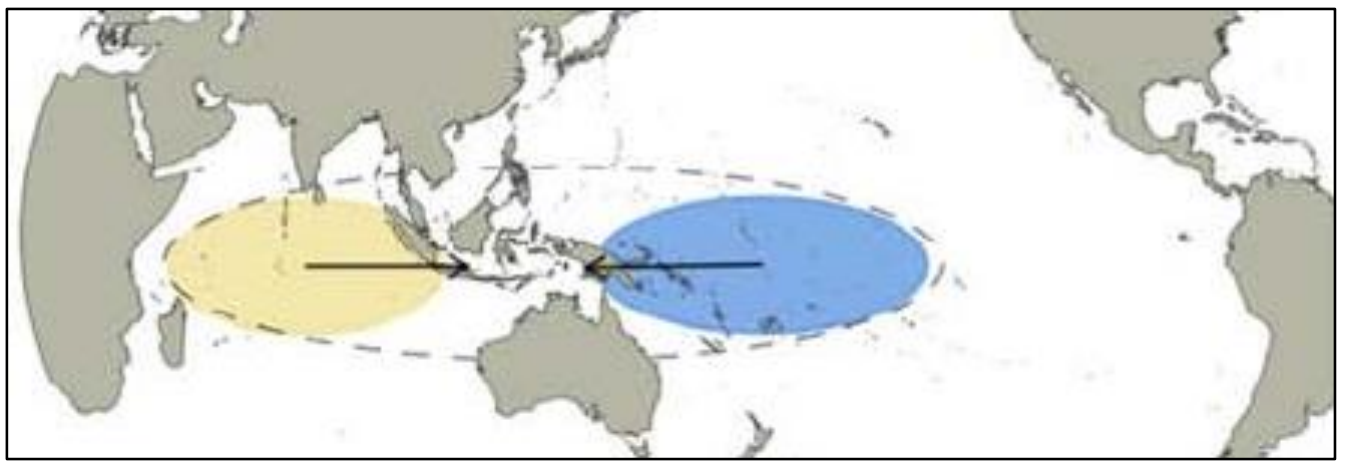

Gambar 7. Model pusat tumpang tindih (Gaboriau et al., 2018). 
2009), Myripristis berndti (Craig et al., 2007) dan Cephalopholis argus (Gaither et al., 2011). Penelitian tersebut mengkonfirmasi bahwa distribusi yang tumpang tindih dari ikan karang yang berasal dari Samudera Pasifik dan Hindia berkontribusi terhadap pusat biodiversitas di kawasan segitiga terumbu karang.

\section{Model Pusat Akumulasi (Center of Accumulation)}

Model pusat akumulasi merupakan kebalikan dari pusat asal-usul (center of origin). Model ini lebih menekankan pada tingginya diversitas ikan pada kawasan segitiga terumbu karang sebagai hasil migrasi spesies yang telah mengalami spesiasi dari lokasi lain (Gambar 8). Peristiwa ini dapat disebabkan karena pola arus air laut dan angin yang cenderung mengarah ke arah segitiga terumbu karang. Menurut Bowen et al., (2013) model pusat akumulasi dipengaruhi oleh wilayah sekitar bagian kawasan segitiga terumbu karang yang tidak termasuk dalam wilayah pusat biodiversitas atau biasa disebut zona periferal. Menurut Craig (2010) zona periferal berperan sebagai eksportir/ kontributor terhadap diversitas biologis dan genetik ikan karang di segitiga terumbu karang. Beberapa contoh hasil penelitian yang mendukung teori pusat akumulasi adalah spesies Scarus rubroviolaceus dan Zebrasoma flavescens yang terdistribusi di perairan segitiga terumbu karang, namun bukti data populasi genetik/filogenetik menunjukkan bahwa larva dari spesies ini masuk dari wilayah Hawaii di masa lalu (Eble et al., 2011; Fitzpatrick et al., 2011).

\section{Model Pusat Pertahanan (Center of Survival/refugia)}

Model ini pertama kali diusulkan oleh Heck and McCoy (1978) yang menyatakan bahwa wilayah segitiga terumbu karang merupakan zona yang potensial untuk pertahanan. Dalam model pertahanan, tingkat kepunahan spesies pada kawasan segitiga terumbu karang dipengaruhi oleh faktor kondisi habitat potensial dari wilayah terumbu karang yang besar. Dalam hal ini, rendahnya diversitas spesies ikan karang yang jauh dari segitiga terumbu karang diakibatkan oleh tingkat kepunahan yang tinggi (Potts, 1983; Quental \& Marshall, 2009). Kondisi habitat pada kawasan segitiga terumbu karang yang stabil selama proses perubahan geologi pada masa lalu berperan sebagai tempat perlindungan bagi spesies dari kepunahan. Seperti diketahui bahwa kepunahan terjadi sebagai akibat hilangnya habitat dan sumber terbentuknya koloni baru pada saat terjadi ketidakstabilan area pada beberapa

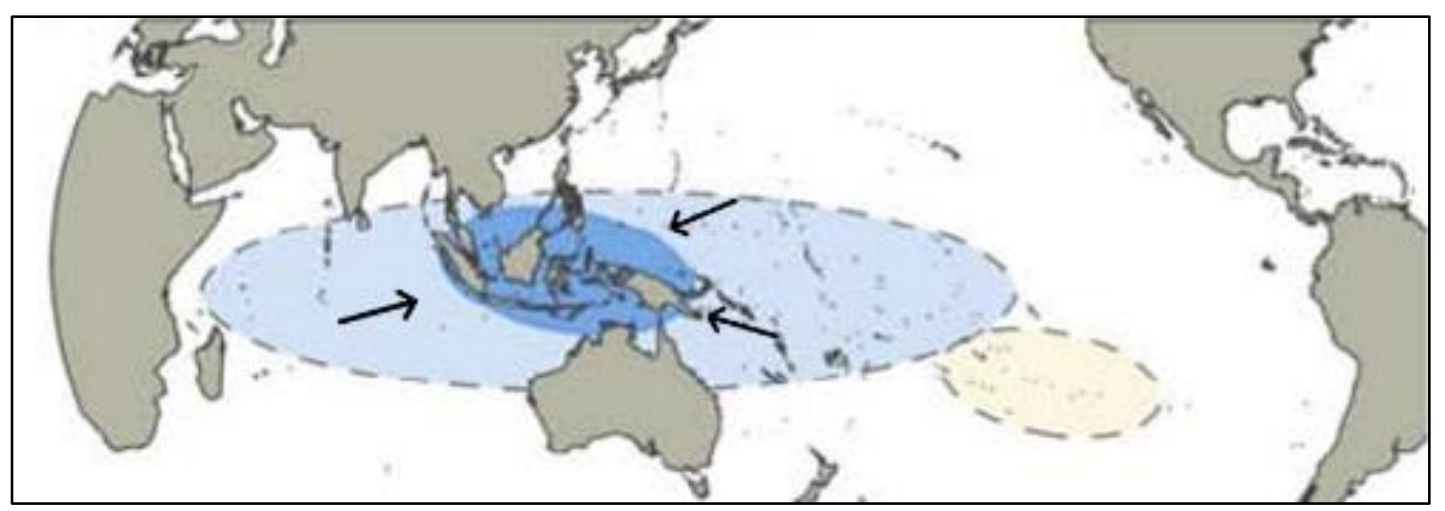

Gambar 8. Model pusat akumulasi (Gaboriau et al., 2018). 
periode masa lalu (Mabuchi et al., 2014; Pellissier et al., 2014; Siqueira et al., 2016). Berdasarkan model paleo habitat yang dibentuknya, penurunan masa air pada sekitar 2,6 juta tahun lalu telah memisahkan laut atlantik dan Indo-Pasifik dan selanjutnya proses fragmentasi (isolasi habitat menjadi bagian-bagian kecil) terjadi berkesinambungan selama proses glasial di era itu, sehingga terjadi banyak spesiasi seperti pada family ikan Pomacentridae, Chaetodontidae dan Labridae. Kondisi habitat terumbu karang yang stabil dibagian Indo-Pasifik (Kawasan segitiga terumbu karang termasuk di dalamnnya) menyebabkan spesiasi yang lebih kontinyu tanpa kepunahan terhadap spesies tetuanya, daripada wilayah lain/periferal yang kurang stabil (Pellissier et al., 2014). Hal ini didukung oleh Evans et al., (2016) yang menekankan pentingnya habitat terumbu karang untuk mencegah terjadinya penurunan biodiversitas pada ikan karang.

\section{The Mid Domain Effect (MDE)/null model}

Dalam model ini biodiversitas ikan yang terjadi di kawasan segitiga terumbu karang merupakan hasil dari fenomena ekologis yang stokastik (acak) dimana menurut Belwood et al., (2005) bahwa memusatnya biodiversitas ikan karang merupakan penempatan geografis yang acak dan tidak memperhatikan mekanisme ekologis tertentu. Proses dalam MDE secara sederhana dijelaskan oleh Colwell et al., (2004) bahwa apabila spesies diibaratkan sebagai titik-titik dalam zona geometris dan kemudian dikocok, maka hasilnya akan selalu berkumpul dalam satu titik yang memusat. Pengunaan model ini dalam menjelaskan biodiversitas masih banyak dikritik karena dinilai tidak cukup untuk menjelaskan fenomena ekologis yang mempengaruhi biodiversitas dan sering tidak diperhitungkan dalam model MDE (Connolly, 2005; Davies et al., 2005; Mcclain et al., 2007).

\section{PENUTUP}

Kawasan segitiga terumbu karang merupakan wilayah dengan biodiversitas ikan tertinggi di dunia, dimana tingkat diversitas yang tinggi merupakan hasil dari proses evolusioner yang disebut dengan spesiasi. Dalam dua dekade terakhir, penelitian dengan menggunakan pendekatan molekular menunjukkan bahwa pentingnya peran tiga model spesiasi seperti spesiasi alopatrik, simpatrik dan parapatrik dalam menjelaskan diversifikasi/keanekaragaman ikan karang yang terjadi di masa lalu, sekarang dan masa mendatang. Secara biogeografis model yang berkaitan dengan petunjuk biodiversitas di kawasan segitiga terumbu karang meliputi: 1) model pusat asal-usul (center of origin), 2) model pusat tumpang tindih (center of overlap), 3) model pusat akumulasi (center of accumulation), 4) model pusat pertahanan (center of survival/refugia) dan 5) the mid domain effect/null model. Berbagai ahli berpendapat bahwa untuk menjelaskan peran biogeografis terhadap biodiversitas ikan di kawasan segitiga terumbu karang tidak bisa hanya dijelaskan oleh satu model saja, namun kemungkinan besar merupakan kombinasi dan variasi dari beberapa model yang telah dijelaskan diatas. Masingmasing model memberikan kontribusi terhadap peran kawasan segitiga terumbu karang sebagai pusat biodiversitas ikan karang dunia, baik sebagai wilayah dengan kondisi geologis yang unik yang menyediakan habitat beragam bagi ikan karang, namun juga menyediakan 
kestabilan habitat dan lingkungan bagi ikan karang. Sehingga konservasi terhadap wilayah ini perlu dilakukan bukan hanya untuk mencegah kerusakan habitat dan kepunahan spesies ikan, namun juga menjaga kawasan ini agar tetap menjadi tempat yang potensial untuk peristiwa evolusioner di masa yang akan datang.

\section{DAFTAR PUSTAKA}

Abbott, R., Albach, D., Ansell, S., Arntzen, J. W., Baird, ... \& Zinner, D. (2013). Hybridization and speciation. Journal of Evolutionary Biology, 26(2): 229-246. https://doi.org/ 10.1111/j.1420-9101.2012.02599.x

Abrar, M. (2011). Biogeografi biota karang: pendekatan teoritis asal usul, sebaran, spesiasi dan keanekaragaman karang dunia. Oseana, 36(4): 31-43. https://doi.org/10. 1017/CBO9781107415324.004

Allen, G. R. (2008). Conservation hospots of biodiversity and endemism for Indo-Pacific coral reef fishes. Aquatic Conservation: Marine and Freshwater Ecosystems, 656(18): 541-556. https://doi.org/10.1002/aqc

Bayer, R. J. (1996). Hybrid Zones and the Evolutionary Process by R. G. Harrison. Madroño; a West American Journal of Botany., 43: 100-102. https://www.biodiversitylibrary.org/ part/171320

Bellwood, D. R., Klanten, S., Cowman, P. F., Pratchett, M. S., Konow, N., \& Van Herwerden, L. (2010). Evolutionary history of the butterflyfishes (f: Chaetodontidae) and the rise of coral feeding fishes. Journal of Evolutionary Biology, 23(2): 335-349. https://doi.org/ 10.1111/j.1420-9101.2009.01904.x

Bellwood, David R., \& Meyer, C. P.
(2009). Searching for heat in a marine biodiversity hotspot. Journal of Biogeography, 36(4): 569-576. https://doi.org/10.1111/j.1365-2699. 2008.02029.x

Bellwood, David R., Renema, W., \& Rosen, B. R. (2012). Biodiversity hotspots, evolution and coral reef biogeography. Biotic Evolution and Environmental Change in Southeast Asia, 82: 216-245. https://doi.org/ 10.1017/cbo9780511735882.011

Bermingham, E., McCafferty, S. S., \& Martin, A. P. (1997). Fish Biogeography and Molecular Clocks: Perspectives from the Panamanian Isthmus. Molecular Systematics of Fishes, 113-128. https://doi.org/10. 1016/b978-012417540-2/50009-9

Blum, S. D. (1989). Biogeography of the chaetodontidae: an analysis of allopatry among closely related species. Environmental Biology of Fishes, 25(1-3): 9-31. https://doi. org/10.1007/BF00002198

Bowen, B. W., Rocha, L. A., Toonen, R. J., \& Karl, S. A. (2013). The origins of tropical marine biodiversity. Trends in Ecology and Evolution, 28(6): 359-366. https://doi.org/10.1016/j. tree.2013.01.018

Briggs, J. C. (1999). Coincident biogeographic patterns: Indo-West Pacific Ocean. Evolution, 53(2): 326-335. https://doi.org/10.1111/j.1558-5646. 1999.tb03769.x

Cabej, N. R. (2012). Species and Allopatric Speciation. Epigenetic Principles of Evolution, 1865, 707-723. https:// doi.org/10.1016/b978-0-12-4158313.00018-5

Connolly, S. R. (2005). the Mid-Domain Effect. The American Naturalist, 166(1): 1-11.

Cook, O.. (1906). Factors of Species- 
Formation. 23(587): 506-507. https: //doi.org/10.1126/science.23.587.506

Cowman, P. F. (2014). Historical factors that have shaped the evolution of tropical reef fishes: A review of phylogenies, biogeography, and remaining questions. Frontiers in Genetics, 5(NOV): 1-15. https://doi. org/10.3389/fgene.2014.00394

Craig, M. T., Eble, J. A., Bowen, B. W., \& Robertson, D. R. (2007). High genetix conectivity across the Indian and Pasfic Oceans in the reef fish Myripristis berndti (Holocentridae). 334: 245-254. h

Davies, T. J., Grenyer, R., \& Gittleman, J. L. (2005). Phylogeny can make the mid-domain effect an inappropriate null model. Biology Letters, 1(2): 143-146. https://doi.org/10.1098/ rsbl.2005.0297

Dawson, M. N., Louie, K. D., Barlow, M., Jacobs, D. K., \& Swift, C. C. (2002). Comparative phylogeography of sympatric sister species, Clevelandia ios and Eucyclogobius newberryi (Teleostei, Gobiidae), across the California Transition Zone. Molecular Ecology, 11(6): 10651075. https://doi.org/10.1046/j.1365294X.2002.01503.x

DiBattista, J. D., Waldrop, E., Bowen, B. W., Schultz, J. K., Gaither, M. R., ... \& Rocha, L. A. (2012). Twisted sister species of pygmy angelfishes: Discordance between taxonomy, coloration, and phylogenetics. Coral Reefs, 31(3): 839-851. https://doi. org/10.1007/s00338-012-0907-y

Eble, J. A., Toonen, R. J., Sorenson, L., Basch, L. V., Papastamatiou, Y. P., \& Bowen, B. W. (2011). Escaping paradise: Larval export from Hawaii in an indo-pacific reef fish, the yellow tang zebrasoma flavescens. Marine
Ecology Progress Series, 428(May):

245-258. https://doi.org/10.3354/ meps09083

Evans, S. M., McKenna, C., Simpson, S. D., Tournois, J., \& Genner, M. J. (2016). Patterns of species range evolution in Indo-Pacific reef assemblages reveal the Coral Triangle as a net source of transoceanic diversity. Biology Letters, 12(6): https://doi.org/10. 1098/rsbl.2016.0090

Fitzpatrick, J. M., Carlon, D. B., Lippe, C., \& Robertson, D. R. (2011). The West Pacific diversity hotspot as a source or sink for new species? Population genetic insights from the Indo-Pacific parrotfish Scarus rubroviolaceus. Molecular Ecology, 20(2): 219-234. https://doi.org/10.1111/j.1365-294X. 2010.04942.x

Gaboriau, T., Leprieur, F., Mouillot, D., \& Hubert, N. (2018). Influence of the geography of speciation on current patterns of coral reef fish biodiversity across the Indo-Pacific. Ecography, 41(8): 1295-1306. https://doi.org/10. 1111/ecog.02589

Gaither, M. R., Bowen, B. W., Bordenave, T. R., Rocha, L. A., Newman, S. J., .. \& Craig, M. T. (2011). Phylogeography of the reef fish Cephalopholis argus (Epinephelidae) indicates Pleistocene isolation across the indo-pacific barrier with contemporary overlap in the coral triangle. BMC Evolutionary Biology, 11(1): https://doi.org/10.1186/14712148-11-189

Gaither, M. R., \& Rocha, L. A. (2013). Origins of species richness in the Indo-Malay-Philippine biodiversity hotspot: Evidence for the center of overlap hypothesis. Journal of Biogeography, 40(9): 1638-1648. 
https://doi.org/10.1111/jbi.12126

Goldberg, E. E., Roy, K., Lande, R., \& Jablonski, D. (2005). Diversity, Endemism, and Age Distributions in Macroevolutionary Sources and Sinks. The American Naturalist, 165(6): 623. https://doi.org/10.2307/ 3473514

Graves, J. E., \& Rosenblatt, R. H. (1980). Genetic Relationships of the Color Morphs of the Serranid Fish Hypoplectrus unicolor. Evolution, 34(2): 240. https://doi.org/10.2307/ 2407388

Harrison, H. B., Berumen, M. L., SaenzAgudelo, P., Salas, E., Williamson, D. H., \& Jones, G. P. (2017). Widespread hybridization and bidirectional introgression in sympatric species of coral reef fish. Molecular Ecology, 26(20): 5692-5704. https:// doi.org/10.1111/mec.14279

Heck, K. L., \& McCoy, E. D. (1978). Longdistance dispersal and the reefbuilding corals of the Eastern Pacific. Marine Biology, 48(4): 349-356. https://doi.org/10.1007/BF00391639

Hewitt, G. M. (2001). Speciation, hybrid zones and phylogeography - Or seeing genes in space and time. Molecular Ecology, 10(3): 537-549. https://doi.org/10.1046/j.1365-294X. 2001.01202.x

Hodge, J. R., \& Bellwood, D. R. (2016). The geography of speciation in coral reef fishes: the relative importance of biogeographical barriers in separating sister-species. Journal of Biogeography, 43(7): 1324-1335. https://doi.org/10.1111/jbi.12729

Hodge, J. R., \& Jcu, R. (2014). Biogeography and the evolution of coral reeffish species, 268.

Hollocher, H. (2013). Speciation, Theories of. Encyclopedia of Biodiversity:
Second Edition, 6: 629-639. https://doi.org/10.1016/B978-0-12384719-5.00130-1

Jones, A. G., Moore, G. I., Kvarnemo, C., Walker, D. E., \& Avise, J. C. (2003). Sympatric speciation as a consequence of male pregnancy in seahorses. Proceedings of the National Academy of Sciences of the United States of America, 100(11): 6598-6603. https://doi.org/10.1073/ pnas. 1131969100

Knowlton, N., \& Weigt, L. A. (1998). New dates and new rates for divergence across the Isthmus of Panama. Proceedings of the Royal Society B: Biological Sciences, 265(1412): 2257-2263. https://doi.org/10.1098/ rspb.1998.0568

Kochzius, M., Seidel, C., Hauschild, J., Kirchhoff, S., Mester, P., .. \& \& Timm, J. (2009). Genetic population structures of the blue starfish Linckia laevigata and its gastropod ectoparasite Thyca crystallina. Marine Ecology Progress Series, 396(Elder 1979): 211-219. https://doi.org/10.3354/meps08281

Leray, M., Beldade, R., Holbrook, S. J., Schmitt, R. J., Planes, S., \& Bernardi, G. (2010). Allopatric divergence and speciation in coral reef fish: The three-spot dascyllus, Dascyllus trimaculatus, species complex. Evolution, 64(5): 1218-1230. https://doi.org/10.1111/j.1558-5646. 2009.00917.x

Levin, R. (1999). Patterns of Evolution. Scientific American Library.

Mabuchi, K., Fraser, T. H., Song, H., Azuma, Y., \& Nishida, M. (2014). Revision of the systematics of the cardinalfishes (Percomorpha: Apogonidae) based on molecular analyses and comparative 
reevaluation of morphological characters. In Zootaxa (Vol. 3846, Issue 2). https://doi.org/10.11646/ zootaxa.3846.2.1

McCartney, M. A., Acevedo, J., Heredia, C., Rico, C., Quenoville, B., ... \& McMillan, W. O. (2003). Genetic mosaic in a marine species flock. Molecular Ecology, 12(11): 29632973. https://doi.org/10.1046/j.1365294X.2003.01946.x

Mcclain, C. R., White, E. P., \& Hurlbert, A. H. (2007). Challenges in the application of geometric constraint models. Global Ecology and Biogeography, 16(3): 257-264. https://doi.org/10.1111/j.1466-8238. 2007.00286.x

Mora, C., \& Sale, P. F. (2002). Are populations of coral reef fish open or closed? Trends in Ecology and Evolution, 17(9): 422-428. https:// doi.org/10.1016/S0169-5347(02) 02584-3

Pellissier, L., Leprieur, F., Parravicini, V., Cowman, P. F., Kulbicki, M., ... \& Mouillot, D. (2014). Quaternary coral reef refugia preserved fish diversity. Science, 344(6187): 1016-1019. https://doi.org/10.1126/science.1249 853

Posadas, P., Crisci, J. V., \& Katinas, L. (2006). Historical biogeography: A review of its basic concepts and critical issues. Journal of Arid Environments, 66(3 SPEC. ISS.): 389-403. https://doi.org/10.1016/ j.jaridenv.2006.01.004

Potts, D. C. (1983). Evolutionary disequilibrium among Indo-Pacific corals. Bulletin of Marine Science, 33(3): 619-632.

Puebla, O., Bermingham, E., Guichard, F., \& Whiteman, E. (2007). Colour pattern as a single trait driving speciation in Hypoplectrus coral reef fishes? Proceedings of the Royal Society B: Biological Sciences, 274(1615): 1265-1271. https://doi. org/10.1098/rspb.2006.0435

Quental, T. B., \& Marshall, C. R. (2009). Extinction during evolutionary radiations: Reconciling the fossil record with molecular phylogenies. Evolution, $\quad 63(12)$ : 3158-3167. https://doi.org/10.1111/j.1558-5646. 2009.00794.x

Ramon, M. L., Lobel, P. S., \& Sorenson, M. D. (2003). Lack of mitochondrial genetic structure in hamlets (Hypoplectrus spp.): Recent speciation or ongoing hybridization? Molecular Ecology, 12(11): 29752980. https://doi.org/10.1046/j.1365294X.2003.01966.x

Randall, J. E. (1998). Zoogeography of shore fishes of the Indo-Pacific region. Zoological Studies, 37(4): 227-268.

Randall, J. E. (2007). Reef and Shore Fishes of the Hawaiian Islands. University of Hawaii Sea Grant College Program.

Randall, J. E., \& Rocha, L. A. (2009). Chaetodontoplus Poliourus, a new angelfish (Perciformes: Pomacanthidae) from the tropical western Pacific. Raffles Bulletin of Zoology, 57(2): 511-520.

Rocha, L A, \& Bowen, B. W. (2008). Speciation in coral-reef fishes. Journal of Fish Biology, 72(5): 11011121. https://doi.org/10.1111/j.10958649.2007.01770.x

Rocha, Luiz A. (2013). Reef Fishes of the East Indies. Volumes I-III. Tropical Reef Research, Perth, Australia. Copeia, 2013(3): 567-568. https:// doi.org/10.1643/ot-13-010

Rocha, Luiz A., Robertson, D. R., Roman, 
J., \& Bowen, B. W. (2005). Ecological speciation in tropical reef fishes. Proceedings of the Royal Society B: Biological Sciences, 272(1563): 573-579. https://doi.org/ $10.1098 / 2004.3005$

Rolán-Alvarez, E. (2007). Sympatric speciation as a by-product of ecological adaptation in the Galician Littorina saxatilis hybrid zone. Journal of Molluscan Studies, 73(1): 1-10. https://doi.org/10.1093/mollus/ eyl023

Roy, K., \& Goldberg, E. E. (2007). Origination, extinction, and dispersal: Integrative models for understanding present-day diversity gradients. American Naturalist, 170(SUPPL.). https://doi.org/10. 1086/519403

Schultz, J. K., Pyle, R. L., DeMartini, E., \& Bowen, B. W. (2007). Genetic connectivity among color morphs and Pacific archipelagos for the flame angelfish, Centropyge loriculus. Marine Biology, 151(1): 167-175. https://doi.org/10.1007/s00227-0060471-5

Schumer, M., Cui, R., Rosenthal, G. G., \& Andolfatto, P. (2015). Reproductive Isolation of Hybrid Populations Driven by Genetic Incompatibilities. PLoS Genetics, 11(3): 1-21. https://doi.org/10.1371/journal.pgen. 1005041

Siqueira, A. C., Oliveira-Santos, L. G. R., Cowman, P. F., \& Floeter, S. R. (2016). Evolutionary processes underlying latitudinal differences in reef fish biodiversity. Global Ecology and
Biogeography, 25(12): 1466-1476. https://doi.org/10.1111/geb.12506

Tornabene, L., Valdez, S., Erdmann, M., \& Pezold, F. (2015). Support for a "Center of Origin" in the Coral Triangle: Cryptic diversity, recent speciation, and local endemism in a diverse lineage of reef fishes (Gobiidae: Eviota). Molecular Phylogenetics and Evolution, 82(PA): 200-210. https://doi.org/10. 1016/j.ympev.2014.09.012

Waldrop, E., Hobbs, J. P. A., Randall, J. E., Dibattista, J. D., Rocha, L. A., ... \& Bowen, B. W. (2016). Phylogeography, population structure and evolution of coral-eating butterflyfishes (Family Chaetodontidae, genus Chaetodon, subgenus Corallochaetodon). Journal of Biogeography, 43(6): 1116-1129. https://doi.org/10.1111/jbi.12680

Wellenreuther, M., Barrett, P. T., \& Clements, K. D. (2007). Ecological diversification in habitat use by subtidal triplefin fishes (Tripterygiidae). Marine Ecology Progress Series, 330(Syms 1995): 235-246. https://doi.org/10.3354/ meps330235

Whitney, J. L., Donahue, M. J., \& Karl, S. A. (2018). Niche divergence along a fine-scale ecological gradient in sympatric color morphs of a coral reef fish. Ecosphere, 9(1). https://doi.org/10.1002/ecs2.2015

Widodo. (2003). Evolusi. UM.

Wu, C. I., \& Ting, C. T. (2004). Genes and speciation. Nature Reviews Genetics, 5(2): 114-122. https://doi.org/10. 1038/nrg1269 